\title{
REORIENTATNG RELIGIOUS EDUCATION IN CREATING ANTIDISCRIMINATIING INDIVIDUALS
}

\author{
Cerly Mariana Damanik, S.Th., M.Pd.K ${ }^{1}$, Marihot Sirait, M.Th², Yuda Morado Marbun, \\ M.Th ${ }^{3}$, Ridwan Marbun, S.Pd.K., M.Th ${ }^{4}$, Ebenezer Parulian Dabukke, M.Pd ${ }^{5}$ \\ \{cerlydamanik@ymail.com ${ }^{1}$, siraitmarihot6@gmail.com ${ }^{2}$, yudamorado@gmail.com ${ }^{3}$, \\ medan.sttbethel@yahoo.com ${ }^{4}$, ebenezerdbk@gmail.com ${ }^{5}$ \}
}

sekolah Tinggi Teologi Bethel-Medan ${ }^{12345}$

\begin{abstract}
Religious education can be an instrument to shape and unify the nation within society. Religious education must constantly be improved to adjust to the changing times; making people aware of science and technology, creative, innovative, and possessing high solidarity; sensitive to the context of national education, the struggles of the nation and answering the needs of believers. Religious education in schools must result in transformation in knowledge (cognitive) and in faith (spiritual) which will give rise to transformation of attitude (affective). This is because one of the goals of religious learning in schools is to enable students to live in harmony with people around who are of various religions and ethnicities. If this is not maximally done, it will cause unexpected problems. One of the issues that arise is the rise of a different understanding of the nature of human beings. Diversity certainly influences a people's perspective on life with each other in the environment in which they lives. When fellow human beings become individuals who love unity without seeing differences amid diversity, we will have realized the true Indonesian citizens with "Bhineka Tungga Ika". Because living together and sharing with others has been the lifestyle of the Indonesian people.
\end{abstract}

Keyword : Education, Religions

\section{Introduction: The Beauty of Togetherness amid diversity}

During the election of the mayor of the city of Medan in 2010, an article in Kompasiana stated that Mr. Sofyan Tan, the "Mayor of the people" would be a mayor believed to be able to lead and win the elections. But that hope was not realized. It is believed the implementation of the elections was fraught with fraud. But an interesting thing that needs to be stated is the experience of researchers who have seen a banner on the A.R. street. Hakim, Medan who stated one statement namely "Don't Choose a Fire Worshiper" and according to the testimony of one teacher who was also a research friend who taught at Sultan Iskandar Muda High School, had also seen a banner that read "Don't Choose a Leader Who Is Not One of Your Religion". At first the researcher saw that it was understandable in the election campaign situation, but when researchers tried to think of it as someone who bears the title of Religious Teacher in this case 
the Christian Religious Teacher. This raises its own unrest for researchers as religious educators because the words in the banners above are words that do not educate the people and even provoke them to look at someone subjectively only when choosing leaders and not their competence, because in reality, dr. Sofyan Tan is still trusted by the Medan city community and even most of the people of North Sumatra especially the Electoral District I namely Medan, Deli Serdang, Tebing Tinggi and Serdang Bedagai chose and entrusted him as the people's messenger in parliament as the Legislative Member of the PDI Perjuangan who now sits on the Commission X of the Republic of Indonesia DPR which deals with education.

Events or events that may be almost similar also occurred at the time of the election of leaders namely the Candidate governeor and vice governor elections in Jakarta which are full of debates over religious and ethnic issues. There are indeed many factors that allow religious and ethnic issues to become a warm discussion at these people's parties. But what researchers want to point out is that the religious issue is still a trend setter. According to researchers, things need to be considered well, it cannot be denied that in politics there are always problems that arise, but do not justify any means let alone use religious / religious issues that are actually sacred and aim to create people who behave properly and correctly and have a sense of togetherness and brotherhood that is good and right. In this case the task of educators including Religious Education educators to raise a serious awareness to achieve "multiculturalism and pluralism education." In order to understand proportionally, inevitably Religious Education must expand its area of study by working together with other educators including educators of other religious teachers such as Islamic religious teachers, Buddhist teachers, Hindu religious teachers and even Gama Kong Hu Chu teachers if possible.

\section{Research Methods}

The research methodology used in this research is the Literature Study Method and Field Observation Method at Sultan Iskandar Muda High School. From the results of the study it was found that there is no religion in Indonesia that teaches Antidiscrimination and intolerance because the estuary of all religions is a good deed that can be felt by everyone even though it is different from him.

\section{Discussion}

\subsection{Trigger of Antidiscrimination Attitude}

Seeing the existence of Indonesian people who have heterogeneity, both religion, ethnicity, and groups, it is necessary to review the direction of Religious Education in a plural society. It is hoped that by teaching Religious Education in the context of a plural society, students will be able to attend and practice their faith in the midst of their environment without compromising the dogma of their faith. This must be understood with the right attitude by every human being. There are several aspects that must be avoided in realizing a harmonious and unified multicultural and anti-discrimination, namely: Primordialism, Ethnocentrism, Discrimination, Stereotypes.

\subsection{Responsibilities of Religious Education}

Religious Education is one of the subject matter which is believed to be able to create a person who loves togetherness. However, one of the problems that is often very sentimental and used 
as a reason for the emergence of multicultural problems is about differences in religion and belief. Religious education carried out in schools is very important in upholding and realizing a peaceful and peaceful society. In the reality of community life there are still many problems that arise with various conflicts that occur that are often associated with religious issues. Religious education is present and presented in the midst of society is to carry out the great commission as in the Word of God. Religious Education which is part of the goals of national education can realize the goals of national education through students. The presence of Religious Education can also be a tool for forming and unifying nations in the midst of diverse societies of different religions, ethnicities, races, classes, etc. In addition, the presence of Religious Education can participate to improve the quality of Indonesian people. Religious Education must continue to develop along with the times; enable humans to be aware of science and technology, be creative, innovative, and have high solidarity; sensitive to the context of national education, the nation's struggle and responding to the needs of believers.

\subsection{Implementation of Multicultural Education in Religious Education Organizing Togetherness Classes}

Religious education and manners in multicultural education can be applied by holding togetherness classes, where all religious teachers, ie teachers of Islam, Christianity, Buddhism and Hinduism, enter one class and teach together, of course, in general material which of course all religions teach it. All participants from each religion will sit in one class together regardless of religious background, ethnicity, race and who are in the class. However, the implementation is not as easy as imagined. The challenge experienced when conducting learning is the existence of indifference from students of different religions when those who deliver the material are religious teachers who are different from their religion. This also results in questions that sometimes go beyond the material limit specified for delivery. The next challenge is that when the religion teacher conveys general material, all students still feel comfortable to pay attention, but it cannot be denied that sometimes conveying material in terms of each religion will reduce the attention of students to pay attention.

The material in religious education subjects is taken from the material with the theme "Love". Love is seen in accordance with the concept of Multicultural learning of all religions, because love is one of the material taught from every religion that is applied by doing good. There is some relevant material but this material is considered sufficient to represent other materials. This material is also seen as the reality of pluralism of plural Indonesian people who are in accordance with the principles of each religion, that is teaching love, even though the terms and basis of the books are different from each religion, but it will certainly lead to a point that is to bring every people in this case is a student pastor to live in goodness and show good deeds in his daily life.

\section{Conclusion}

The implementation of the unity class is an effort to foster a sense of togetherness in diversity. It can be concluded that a sense of togetherness will be created and harmony will be achieved as the hope of everyone.

Through religious education students become aware that God Almighty is the author of diversity or diversity, namely tribes, nations, races, cultures, geographies, religions, customs and habits. 
Diversity undeniably influences outlook of the surrounding environment. However, the dignity of all humans before the Almighty God is equal. Therefore, everyone is called to accept and appreciate the various differences that are reasonable and rational.

In responding diversity, the reference is the doctrine of love and kindness where all religious teachings promote it and every human being longs for a harmonious atmosphere and also creates a humane individual by maintaining friendships regardless of the various differences that contain feelings sympathy and empathy for fellow human beings who are brothers and sisters in life wherever they are.

\section{References}

[1] Indonesia, Pendidikan dan Kebudayaan Repulik Indonesia: Pendidikan Agama Kristen dan Budi Pekerti. Jakarta: Kementrian Pendidikan dan Kebudyaan (2015).

[2] Indonesia, Pendidikan dan Kebudayaan Repulik Indonesia: Pendidikan Agama Islam dan Budi Pekerti. Jakarta: Kementrian Pendidikan dan Kebudyaan (2015).

[3] Indonesia, Pendidikan dan Kebudayaan Repulik Indonesia: Pendidikan Agama Budha dan Budi Pekerti. Jakarta: Kementrian Pendidikan dan Kebudyaan (2015).

[4] Indonesia, Pendidikan dan Kebudayaan Repulik Indonesia. Pendidikan Agama Hindu dan Budi Pekerti. Jakarta: Kementrian Pendidikan dan Kebudyaan (2015).

[5] Yayasan Perguruan Sultan Iskandar Muda: Merawat Keberagaman. Praksis Pendidikan Multikultural di Yayasan Perguruan Sultan Iskandar Muda (2015).

[6] Sugiyono. Prof. Dr: Metode Penelitian Manajemen. Bandung: Alfabeta (2014).

[7] Suryabrata. Sumadi. B.A., Drs., M.A., Ed.S., Ph.D): Metodologi Penelitian. Jakarta: Rajagrafindo Persada (2012).

[8] Pendidikan Agama Kristen oleh Dosen Agama Kristen Trisakti Penerbit Universitas Trisakti Jakarta (2000).

[9] PAK dalam Masyarakat Majemuk oleh Dosen STT Bethel Medan 2016.

[10] Kompilasi peraturan perundang-undangan kerukunan hidup umat beragama edisi kelima, Jakarta Balitbanng Agama proyek peningkatan kerukunan hidup umat beragama 1996/1997.

[11] https://issuu.com/andalas/docs/e-paper_andalas_edisi_selasa_4_mei_2010. Diunduh tgl 08 April 2017.

[12] http://www.bbc.com/indonesia/berita indonesia/2016/02/160205 indonesia_evakuasi_ah madiyah. Diunduh tgl 08 APril 2017. 